\title{
Vertical and time distribution of Pseudoscorpiones (Arthropoda: Arachnida) in a floodplain forest in the Brazilian Pantanal
}

\author{
Leandro Dênis Battirola ${ }^{1}$, Germano Henrique Rosado-Neto², Daniel Augusto Batistella ${ }^{1}$, \\ Volker Mahnert ${ }^{3}$, Antonio Domingos Brescovit ${ }^{4} \&$ Marinêz Isaac Marques ${ }^{5}$ \\ 1. Instituto de Ciências Naturais, Humanas e Sociais (Universidade Federal de Mato Grosso), Av. Alexandre Ferronato \\ 1.200, Setor Industrial, 78557-267, Sinop-MT, Brasil; 1dbattirola@uol.com.br, batistella_@hotmail.com \\ 2. Departamento de Zoologia (Universidade Federal do Paraná). Centro Politécnico, Caixa Postal 19020, 81531-980 \\ Curitiba-PR, Brasil; ghrosado@gmail.com \\ 3. Muséum d'Histoire Naturelle, Genève, Switzerland; volker.mahnert@wanadoo.fr \\ 4. Laboratório Especial de Coleções Zoológicas, Instituto Butantan, Av. Vital Brasil 1.500, Butantã, 05503-900, São \\ Paulo-SP, Brasil; Pesquisador bolsista produtividade CNPq; adbresc@terra.com.br \\ 5. Instituto de Biociências, Universidade Federal de Mato Grosso, Av. Fernando Corrêa da Costa 2.367, Boa Esperança, \\ 78060-900 Cuiabá-MT, Brasil; marinez513@gmail.com
}

\section{Received 03-V-2016. Corrected 12-I-2017. Accepted 31-I-2017.}

\begin{abstract}
Pseudoscorpions embrace a diverse group of arachnids with approximately 3500 species that occur in various habitats, such as soil, leaf litter, caves and canopies. This study aimed at evaluating the relationship between the pseudoscorpion assemblages in soil, termite nests, tree trunks and canopies, as well as the temporal distribution as to the abundance and richness of species in these habitats. For this purpose different sampling techniques were applied in an integrated manner in distinct habitats of a seasonally flooded monodominant forest in the Northern Pantanal of Mato Grosso, Brazil. Data regarding the abundance and richness of assemblage species were organized by means of the Non-Metric Multidimensional Scaling (NMDS). A total of 2068 Pseudoscorpiones distributed in seven families and 18 species were captured. Chernetidae $(8 \mathrm{spp}$.) and Withiidae (5 spp.) predominated, while Atemnidae, Cheiridiidae, Geogarypidae, Lechytiidae and Olpiidae were present with only one species each. Terrestrial fauna was more abundant (1035 ind.; $50.0 \%$ of the total catch) with three families and 10 species. In the arboreal fauna (712 ind.; $34.4 \%$ ), four families and 13 species were found. Termite mounds (321 ind.; $15.6 \%$ ) corresponded to the habitat with the least number of individuals, however, five families and nine species were identified, including Parachernes sp. 2, Geogarypus sp. and Olpiolum sp., not found in other analyzed habitats in this forest. The analyses did not show any temporal variation as to abundance or richness of Pseudoscorpiones in each evaluated habitat; however, the analysis showed that the edaphic environment (soil + termite nests), tree trunks and tree canopies are distinct habitats in relation to the composition of the assemblage. The occurrence of typical terricolous (e.g. Parawithius sp., Withiidae gen. sp. and Parachernes sp.) and other arboricolous (e.g. Cheiridium sp., Americhernes sp. and Lustrochernes sp.) species highlights the vertical stratification of the assemblage present in this floodplain forest in the Pantanal of Mato Grosso. Rev. Biol. Trop. 65 (2): 445-459. Epub 2017 June 01.
\end{abstract}

Key words: Chernetidae, flood areas, richness, vertical distribution, Withiidae.

Floodplains, especially the Brazilian Pantanal, are characterized by the controlling influence of flood pulses and vegetation, which have a major impact on the population dynamics of species, thereby influencing community structure (Junk, Bayley, \& Sparks, 1989; Junk, 1997). In the Pantanal, the association of its geological and geomorphological history, results in a variety of landscapes, vegetation types (including monodominant forests), and habitats with specific characteristics, constituting real vegetation mosaics (Silva, Mauro, Mourão, \& Coutinho, 2000; Nunes-da-Cunha \& Junk, 2011). The annual and multi-annual 
variability of the flood pulse affects the biota at different intensities and time scales (Nunes-daCunha \& Junk, 2004), causing terrestrial organisms to develop specific strategies to survive and adapt to the strong seasonality, characteristic of this floodplain (Adis, Marques, \& Wantzen, 2001; Battirola, Marques, Rosado-Neto, Pinheiro, \& Pinho, 2009).

As in other regions of South America in the Brazilian Pantanal (e.g. Mahnert \& Adis, 2002), the knowledge about ecological and taxonomical diversity of pseudoscorpions is under explored, as well as their relationship with the different habitats. The Pseudoscorpiones are arachnids that can occupy a variety of terrestrial habitats, mainly edaphic and cave environments (Murienne, Harvey, \& Giribet, 2008), and can colonize the forest canopy (Mahnert \& Adis, 1985; Adis, Mahnert, De Morais, \& Rodrigues, 1988; Battirola, Adis, Marques, \& Silva, 2007; Mahnert, 2009; Marques, Adis, Battirola, Santos, \& Castilho, 2011), or live associated with the nests of social insects, birds and mammals (Mahnert \& Adis, 2002). Estimates show that the order Pseudoscorpiones has 3533 species worldwide (Harvey, 2013), although earlier projections had already estimated that the number was close to 5000 species (Adis \& Harvey, 2000; Adis, 2002).

In Brazil, most of the ecological studies on Pseudoscorpiones were carried out in the Central Amazon (Adis, 1981; Adis \& Mahnert, 1985; 1990, a, b; 1993; Mahnert \& Adis, 1985; De Morais, Adis, Mahnert, \& Berti-Filho, 1997; Aguiar \& Bührnheim, 1998, a, b; 2003; Aguiar, Gualberto, \& Franklin, 2006). Some populations of Pseudoscorpiones may have undergone extensive evolution within inundation forests in this region, due to forest isolation caused by climatic shifts and micro-geographic changes (Adis \& Schubart, 1984). In these environments the terricolous species use the soil and leaf litter as a breeding place during the non-flooded period and migrate later to tree trunks and regions of the forest canopy, where they remain during the flood periods (Adis \& Mahnert, 1990a; Adis, 1997; Mahnert \& Adis,
2002). Other species are strictly inhabitants of the forest canopy (Adis et al., 1988).

Considering the diversity of habitats in inundated forests and the influence of seasonal variations on the Pseudoscorpiones assemblage, different sampling techniques were applied in an integrated way in this study, in order to assess (i) the abundance and richness of Pseudoscorpiones in the soil, leaf litter, termite nests, tree trunks and canopies in an inundated forest of Vochysia divergens (Vochysiaceae) in the Northern region of the Brazilian Pantanal; (ii) evaluate the occurrence over the different seasonal periods of the region and (iii) verify if there is habitat specificity among the Pseudoscorpiones which use this area.

\section{MATERIAL AND METHODS}

Study area: This study was carried out in the Pantanal of Poconé $\left(16^{\circ} 15^{\prime} \mathrm{S}-56^{\circ} 36^{\prime}\right.$ W) in the municipality of Nossa Senhora do Livramento, Mato Grosso, Brazil. Sampling was carried out between January 2004 and March 2005, in an inundated forest with predominance of $V$. divergens (Vochysiaceae), which represents one of the region's typical phytofisionomies, called "cambarazal" (Nunesda-Cunha \& Junk, 2014). The sampling with the Winkler extractor was performed between 1999 and 2000.

This region is characterized by four welldefined seasonal periods (Heckman, 1998). The dry season occurs between July and September. In this period most of the Northern Pantanal is completely dry and rainfall is scarce. The start of the rainy season corresponds to the rising water period (between October and December), when some areas may flood up temporarily with water from the rains, but become dry again after periods of sun. The high water period generally occurs between January and March or April. In this period much of the Northern region of the Pantanal is submerged, fields and forests are flooded due to the overflow of rivers and lakes. The receding water season is the period in which the water level in flooded areas drains rapidly, accompanied by reducing 
the amount of rainfall in the region, recorded between April and June.

Field procedures: Different collection methodologies were employed for the soil and leaf litter, tree trunks and canopies in the dry, rising water, high and receding water periods (e.g. Adis, 1981; 2002; Battirola et al., 2009). Only the collections from termite mounds and trunks following the waterline were performed exclusively during the high water period, aiming to evaluate specifically this period. Details of each methodology applied are presented below:

a. Pitfall traps: These traps consist of a $20 \mathrm{~cm}$ polyethylene flask with a round nozzle of 5-6 cm (Adis, 2002) (Fig. 1A). A total of 10 unbaited traps were distributed unsystematically in the "murundus" (Ponce \& Nunes-da-Cunha, 1993; Por, 1995), termite earth mounds that are not submerged in the flood period in the "cambarazal". Seven traps were filled with $250 \mathrm{~mL}$ water solution with picric acid, and three with a $4 \%$ formalin solution. These traps were checked each 15 days, from January 2004 to January 2005 to analyze the activity density of Pseudoscorpiones on the soil.

b. Soil photoeclectors: These traps are a round apparatus with a base area of $1 \mathrm{~m}^{2}$ covered with a black fabric with a plastic transparent collecting recipient at the top - containing a water solution with picric acid (250 mL) (Adis, 2002) (Fig. 1B). Three photoeclectors were installed, which represents a sampling area of $3 \mathrm{~m}^{2}$ and remained installed throughout the whole sampling period (January 2004 to January 2005). The material collected was removed every 15 days, to assess the emergence density of the Pseudoscorpiones based on the relationship between the numbers of individuals collected per area. The material collected on February $29^{\text {th }} 2004$ was lost due to extreme flooding on that day.

c. Termite mounds: To evaluate Pseudoscorpiones associated with termite nests, four mounds within the forest and in contact with water were selected (March 2004) (Fig. 1F). These mounds had the apical portion, above the water level, cut with an electric saw, packed in plastic bags, and transported to the laboratory for manual collection of the pseudoscorpions.

d. Winkler extractor: Samples were collected in February (high water), May (receding water), October (dry season), and December (rising water) of 2000 (Pinho, 2003). A total of $38 \mathrm{~m}^{2}$ of surface soil (0 to 5 $\mathrm{cm})$ and leaf litter were sampled, with $10 \mathrm{~m}^{2}$ in the high water, dry season, and rising water periods, and $8 \mathrm{~m}^{2}$ during the receding water period. Details about the equipment utilized for these samplings are given in Castilho, Marques, Adis, and Brescovit (2005).

e. Trunk photoeclectors: These traps consist of black fabric capturing funnels $(74 \mathrm{~cm})$, forming a ring around the trunks fixed by a $22 \mathrm{~cm}$ L-shaped metallic support (Adis, 2002). Each trap has a transparent collecting device containing $350 \mathrm{~mL}$ of water solution with picric acid. In order to monitor the activity of the groups that migrates between the soil and the canopy. Three trunk photoeclectors were used: (I) one for collecting organisms that migrate from the soil to the canopy installed five meters from the ground (Fig. 1C); (II) another in the same direction, but installed $50 \mathrm{~cm}$-high from the ground, and with a shorter time interval (October 2004 to March 2005) in order to intercept those Pseudoscorpiones located over the trunk along the waterline and which therefore do not reach the highest parts of the trunk; (III) a third one was installed in order to intercept those individuals migrating from the canopy to the soil which was also placed five meters from the ground (Fig. 1D). All of them were installed on the trunks with $V$. divergens in the central area of the forest and were monitored every 15 days between January 2004 and March 2005. 

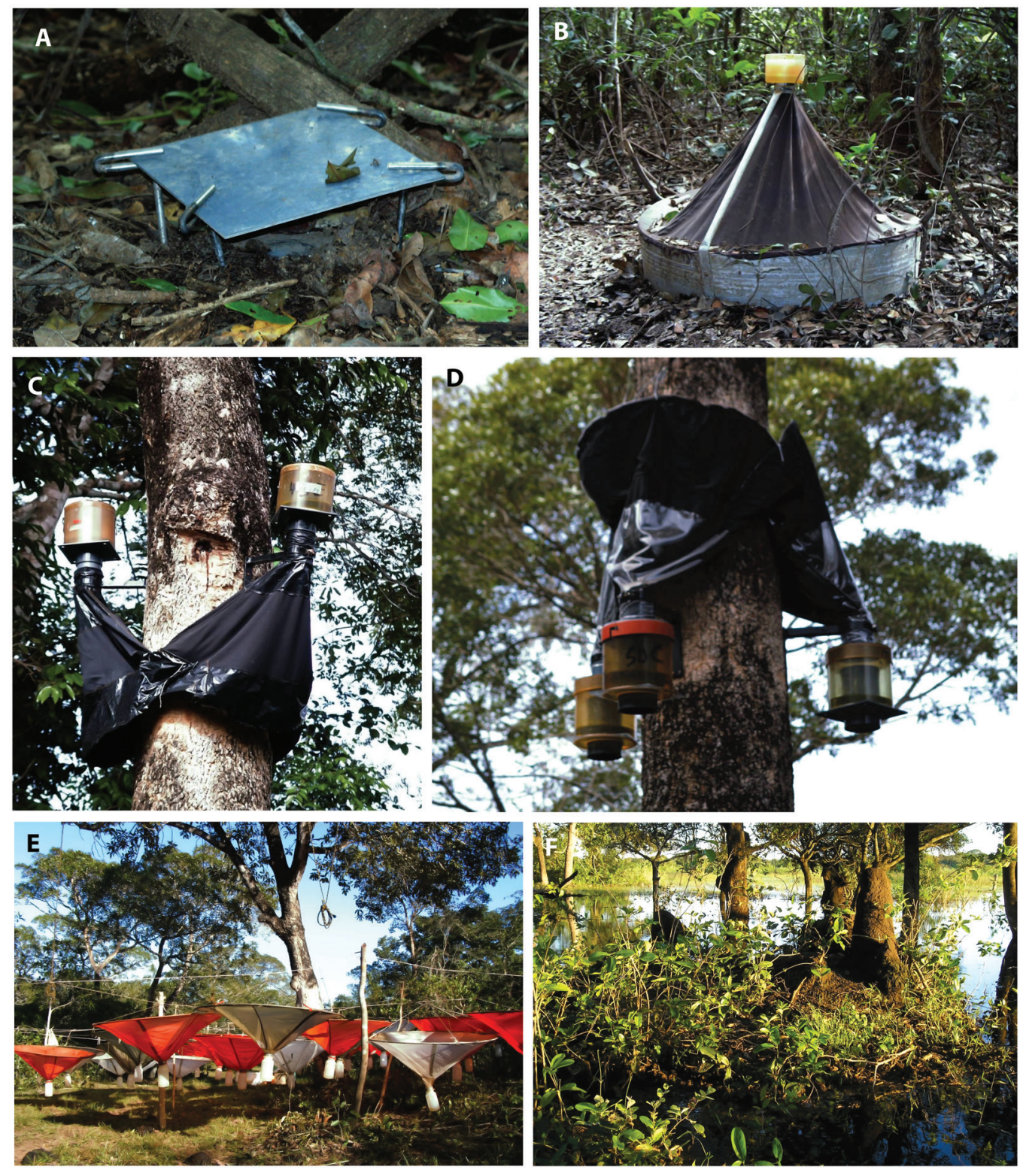

Fig. 1. Methods employed in the sampling of Pseudoscorpiones in a seasonally flooded $V$. divergens Pohl. (Vochysiaceae) monodominant forest in the Brazilian Pantanal: A: Pitfall traps; B: Soil photoeclector; C: Trunk photoeclector (soil to canopy); D: Trunk photoeclector (canopy to soil); E: Fogging (canopy fogging); F: Murundus associated with termite mounds within the forest (Pictures: Leandro Battirola).

f. Trunk along the waterline: During the high water season in the forest (March 2004), three specimens of $V$. divergens $(\mathrm{DAP}=$ $30 \mathrm{~cm}$ ) located in the central portion of the forest were selected to evaluate the arthropods associated with their trunks, specifically its bark, by following the waterline during this period. Three heights were delimited in these trunks: 0-20, 21-40, and $41-60 \mathrm{~cm}$ above the waterline. During 
this period, the water level in the forest reached a depth of $0.8 \mathrm{~m}$. The previously delimited parts of the trunks were scraped superficially with a machete until all cork layer was extracted. The material was placed in a plastic tray and later transferred to plastic containers with $92 \%$ alcohol for subsequent testing.

g. Canopy fogging: A total of 12 samples by fogging were carried out during the four seasonal periods (high water/February 2004; receding water/May 2004; dry season/September 2004 and rising water/ December 2004), making a total of $396 \mathrm{~m}^{2}$ of canopies sampled (Fig. 1E). In each period three individuals of $V$. divergens with $33 \mathrm{~m}^{2}$ of canopy area were fogged, in a total of $99 \mathrm{~m}^{2}$ per seasonal period. Sampled trees were selected according to the criteria proposed by Adis, Basset, Floren, Hammond, and Linsenmair (1998), and the methodological procedures as presented by Battirola, Marques, Adis, and Brescovit (2004) and Marques, Adis, Santos, and Battirola (2006).

The pseudoscorpions coming from the samples were screened at the Laboratório de Ecologia e Taxonomia de Artrópodes (LETA) of the Instituto de Biociências, Universidade Federal de Mato Grosso in Cuiabá, MT, and subsequently deposited in the Museu de Zoologia at the Universidade de São Paulo (MZSP). The identification was made by the expert on Pseudoscorpiones taxonomy Prof. Dr. Volker Mahnert (Muséum d'Histoire Naturelle, Genève, Switzerland) (Mahnert \& Adis, 2002; Harvey, 2013). Data from the Pseudoscorpiones assemblage were ordered by means of the Non-Metric Multidimensional Scaling (NMDS) for the results as to numerical abundance (quantitative) and presence-absence (qualitative) of species, in order to reduce the dimensionality of information from multiple taxa (Clarke, 1993). This procedure shows the variation magnitude captured by one, two, or more dimensional solutions. The dissimilarity between the sampling units was calculated using the associative matrix by means of the Bray-Curtis and Sørensen Index (Legendre \& Legendre, 1998). The Multivariate Analysis of Variance (MANOVA) was employed while using the NMDS two dimensions with data abundance and presence or absence. These analyzes test the existence of average differences in the composition of the Pseudoscorpiones assemblage using categorical variables referring to seasonal periods (high water, receding water, dry season and rising water) and data from extract (soil and litter, tree trunks, termite nests and canopy assemblages). Analyses were carried out using the free software R 2.12.1 (R Development Core Team, 2013), Vegan package (Oksanen et al., 2014).

\section{RESULTS}

A total of 2068 Pseudoscorpiones distributed in seven families and 18 species were captured (Table 1). Chernetidae (8 spp.) and Withiidae (5 spp.) were predominant. Atemnidae, Cheiridiidae, Geogarypidae, Lechytiidae and Olpiidae presented only one species each. The individuals of Chernetidae juv. (Parachernes) were not identified as a species. Terrestrial fauna (1035 individuals, $50.0 \%$ of the total catch), with three families and 10 species identified, were more abundant than the arboreal fauna (712 ind.; $34.4 \%$ ), with four families and 13 species. Although termite nests (321 ind.; $15.6 \%$ ) have corresponded to the habitat with the least number of individuals, five families and nine species were identified.

Topsoil and leaf litter: Using the Winkler extractor 840 Pseudoscorpiones $(43.7 \%$ of the total number captured, 22.1 ind. $/ \mathrm{m}^{2}$ ) were sampled. These were represented by only two families and three species, Parachernes sp. (Chernetidae), Parawithius sp. and Withiidae gen. sp. (both Withiidae) (Table 1). Topsoil (435 ind.; $51.8 \%, 11.3$ ind. $/ \mathrm{m}^{2}$ ) and leaf litter (405 ind.; $48.2 \% ; 10.7$ ind. / $\mathrm{m}^{2}$ ) were similar in terms of pseudoscorpion abundance and richness. Parawithius sp. was the dominant species over all seasonal periods (785 ind.; $93.5 \%$; 


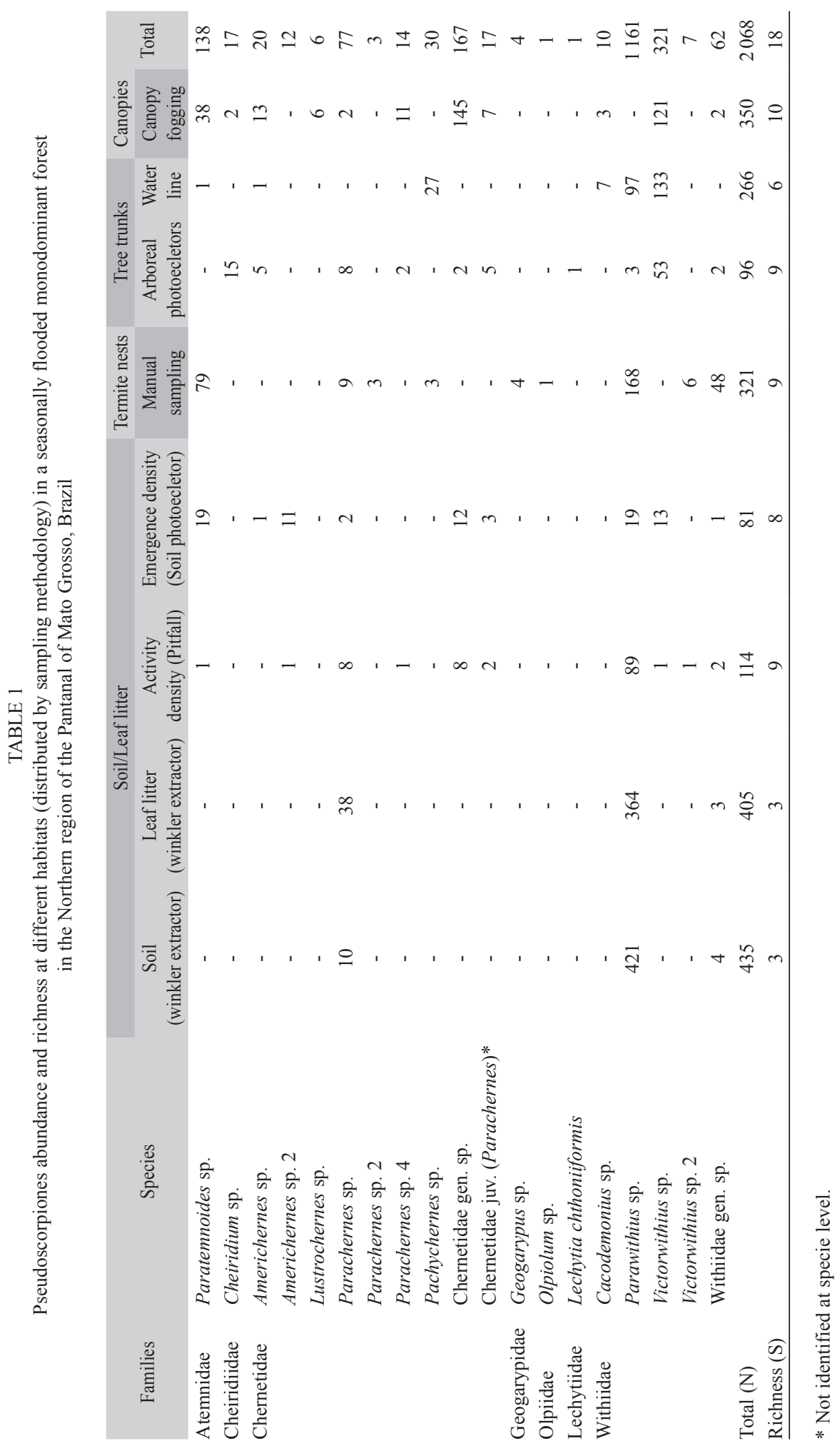


20.7 ind. $/ \mathrm{m}^{2}$ ), both in soil (421 ind.; $53.6 \%$; 11.1 ind. $/ \mathrm{m}^{2}$ ) and in leaf litter (364 ind.; 46.4 $\%$; 9.6 ind. $/ \mathrm{m}^{2}$ ). With regards to abundance distribution among the seasonal periods, higher values of abundance were observed during the flood period, both on the topsoil (286 ind.; 65.7 $\%$ of the total catch in soil; 28.6 ind. / $\mathrm{m}^{2}$ ), and in leaf litter (245 ind.; $60.5 \%$; 24.5 ind. / $\mathrm{m}^{2}$ ). However, no significant mean differences in the distribution of Pseudoscorpiones over the seasonal periods were recorded.

\section{Density of activity and emergence in soil:} A total of 114 Pseudoscorpiones were captured on the soil surface with pitfall traps $(5.5 \%$ of the total catch), representing three families and nine species (Table 1). Parawithius sp. (Withiidae) presented greater activity density (78.1 \%; 89 ind.), followed by Parachernes sp. and Chernetidae gen. sp. (7.2\%; 8 ind. each) (Chernetidae). The other species had only one individual sampled. Activity concentration was higher in the high water season $(39.5 \% ; 45$ ind.) and low water season (36.9\%; 42 ind.). During the high water period the greatest activity was observed in February (29.2 \%; 34 ind.), the month in which the flood water reached its maximum height in the "cambarazal" (1.25 m). Parawithius sp. (78.1 \%; 89 ind.) presented activity throughout the year, with the highest densities during the high water season (46.1 $\%$; 41 ind.) and low water season (32.6\%; 29 ind.). The low water season was also the period of highest activity on the soil for Parachernes sp. (62.5\%; 5 ind.) and Chernetidae gen. sp. (50.0\%; 4 ind.). Low density activity was recorded for Victorwithius sp., Victorwithius sp. 2, Parachernes sp. 4, Withiidae gen. sp., Americhernes sp. 2 and Paratemnoides sp.

Using soil photoeclectors 81 individuals were captured (2.1 ind. $/ \mathrm{m}^{2} /$ month) representing $3.9 \%$ of the total Pseudoscorpiones sampled in the "cambarazal", distributed in three families and eight species (Table 1). Paratemnoides sp. (19 ind.; 0.5 ind. / $\mathrm{m}^{2} /$ month) and Parawithius sp. (19 ind.; 0.5 ind. $/ \mathrm{m}^{2} /$ month) predominated, followed by Victorwithius sp. (13 ind.; 0.3 ind. $/ \mathrm{m}^{2} /$ month),
Chernetidae gen. sp. (12 ind.; 0.3 ind. / $\mathrm{m}^{2} /$ month), and Americhernes sp. 2 (11 ind.; 0.3 ind. / $\mathrm{m}^{2} /$ month). The emergence dominance occurred during the flood period $(44.5 \%, 4.0$ ind. / $\mathrm{m}^{2} /$ month). No significant mean differences were registered between the activity density and Pseudoscorpiones emergency over the seasonal periods.

Pseudoscorpiones associated with termite mounds: Associated with termite mounds were sampled 321 Pseudoscorpiones (16.7\% of the total sample), being divided into five families and nine species (Table 1). The most abundant species were Parawithius sp. (52.3\%; 168 ind.) and Paratemnoides sp. (24.6\%; 79 ind.) both being represented by individuals of all developmental stages. Withiidae gen. sp. and Victorwithius sp. 2 occurred only in one of the four evaluated termite mounds, with adult and immature representatives. Geogarypus sp. and Parachernes sp. 2 were also captured in a single mound, only with adult individuals, while Parachernes sp. and Olpiolum sp. presented only immature individuals.

Density of activity on tree trunks: On the tree trunks, in the direction soil towards the canopy, only 18 Pseudoscorpiones $(0.9 \%$ of the total catch) were captured, 14 in the traps installed at a height of $5 \mathrm{~m}$ and four in traps located at a height of $0.5 \mathrm{~m}$, representing four families and six species. In the direction of canopy to soil 78 individuals $(3.9 \%$ of the total catch) were collected in three families and six species (Table 1).

With the traps installed at $5 \mathrm{~m}$ height it can be considered that the flood period was the period of highest activity (35.7\%; 5 ind.) with registration of Victorwithius sp. and Lechytia chthoniiformis (Balzan, 1887). In the photoeclectors installed at $0.5 \mathrm{~m}$ in height between October 2004 and March 2005, there were shifts in the direction of soil toward the canopy only in December $(50.0 \%$; 2 ind.) and again in February (50.0\%; 2 ind.), shortly after the forest was flooded, with the capture of immature Parawithius sp. In the direction canopy 
towards the soil, increased activity was recorded for Victorwithius sp. (62.8\%; 49 ind.), with the presence of all stages of development, followed by Cheiridium sp. (16.7 \%, 13 ind.). No significant mean differences between the activity density on $V$. divergens tree trunks over the seasonal periods were registered.

Fauna associated with tree trunks (water line): A total of 266 Pseudoscorpiones ( $12.9 \%$ of the total sample) was found associated with the barks of $V$. divergens, accompanying the waterline during the high water period of the forest, represented by three families and six species (Table 1). Among the sampled taxa Victorwithius sp. (133 ind.; $50.0 \%$ ) and Parawithius sp. (97 ind.; $36.5 \%$ ) stand out. The other species sampled on the waterline were less abundant in the remaining habitats evaluated (soil and canopy), such as Pachychernes sp. (27 ind.; $10.1 \%$ ), Cacodemonius sp. (7 ind.; $2.6 \%)$, Americhernes sp. (1 ind.; $0.4 \%$ ) and Paratemnoides sp. (1 ind.; $0.4 \%$ ). Most species have a preference for regions of the trunk between 21 and $40 \mathrm{~cm}$ above flood level (182 ind.; $68.4 \%$ ). Between 0 and $20 \mathrm{~cm}$ only 41 individuals $(15.4 \%)$ were captured and between 41 and $60 \mathrm{~cm}$ above the waterline 40 specimens $(15.0 \%)$ were recorded.

Vochysia divergens canopies: A total of 350 Pseudoscorpiones (16.9\% of the total catch, 0.9 ind. $/ \mathrm{m}^{2}$ ) were sampled in $V$. divergens canopies, corresponding to four families and 10 species (Table 1). Chernetidae gen. sp. was most abundant (145 ind.; $41.5 \%$; 0.4 ind. $/ \mathrm{m}^{2}$ ), followed by Victorwithius sp. (121 ind.; $34.7 \%, 0.3$ ind. $/ \mathrm{m}^{2}$ ) and Paratemnoides sp. $\left(10.9 \%, 38\right.$ ind.; 0.1 ind. / $\left.\mathrm{m}^{2}\right)$. No significant mean differences were found between the abundance and richness of Pseudoscorpiones in this habitat over seasonal periods, however, dry (183 ind.; $52.3 \% ; 0.5$ ind. / $\mathrm{m}^{2}$ ) and rising water (112 ind.; $32.0 \%$; 0.3 ind. $/ \mathrm{m}^{2}$ ) periods were most representative. Americhernes sp. was sampled only at high water season (13 ind.; $3.7 \%$; $<0.1$ ind. $/ \mathrm{m}^{2}$ ) and Parachernes sp. 4 occurred, preferably in the rising water season (10 ind.; $90.9 \%$; 0.3 ind. $/ \mathrm{m}^{2}$ ).

Vertical distribution: The assemblage of the Pseudoscorpiones in the different habitats of the "cambarazal" is represented by 18 species, distributed in seven families. Chernetidae was the family with the largest number of species and Withiidae was the most abundant. Among the forest strata evaluated, the edaphic stratum (ground + termite mounds) corresponded to the greater number of species (14 spp.), followed by the tree trunk (12 spp.) and $V$. divergens canopies (10 spp.). NMDS ordering analysis in two axes related to the distribution of Pseudoscorpiones based on the abundance of species in each habitat, captured $63 \%$ of the data (Stress $=0.1)$, indicating that the distribution of species abundance varied between evaluated strata (MANOVA: Pillai Trace $=0.52, \mathrm{~F}_{3.61}=$ 7.13, $\mathrm{P}<0.01$ ) (Fig. 2). The same was observed in relation to species richness in that the NMDS ordering in two axes, captured $61 \%$ of the data (Stress $=0.12$ ), showing a significant change in the distribution of species richness between the strata (MANOVA: Pillai Trace $=0.65, \mathrm{~F}_{3.61}=$ 4.73, $\mathrm{P}<0.01$ ) (Fig. 3).

Thus, the distribution of species in the different strata of this floodplain forest is not homogenous, with typical terrestrial species such as Parawithius sp., Withiidae gen. sp. Parachernes sp. and Americhernes sp. 2 and arboreal species such as Chernetidae gen. sp., Cheiridium sp., Americhernes sp., Lustrochernes sp. Parachernes sp. 4, Lechytia chthoniiformis and Victorwithius sp. which showed association with the canopy and regions of the tree trunks in "cambarazal". Paratemnoides sp. occurred in all segments, while Geogarypus sp., Parachernes sp. 2 and Olpiolum sp. were sampled only in termite mounds. This vertical distribution is evidenced by gradient analysis based on the height of the analyzed habitats, verifying that the habitats are distinct with respect to the assemblage of Pseudoscorpiones that harbor therein (Fig. 4). 


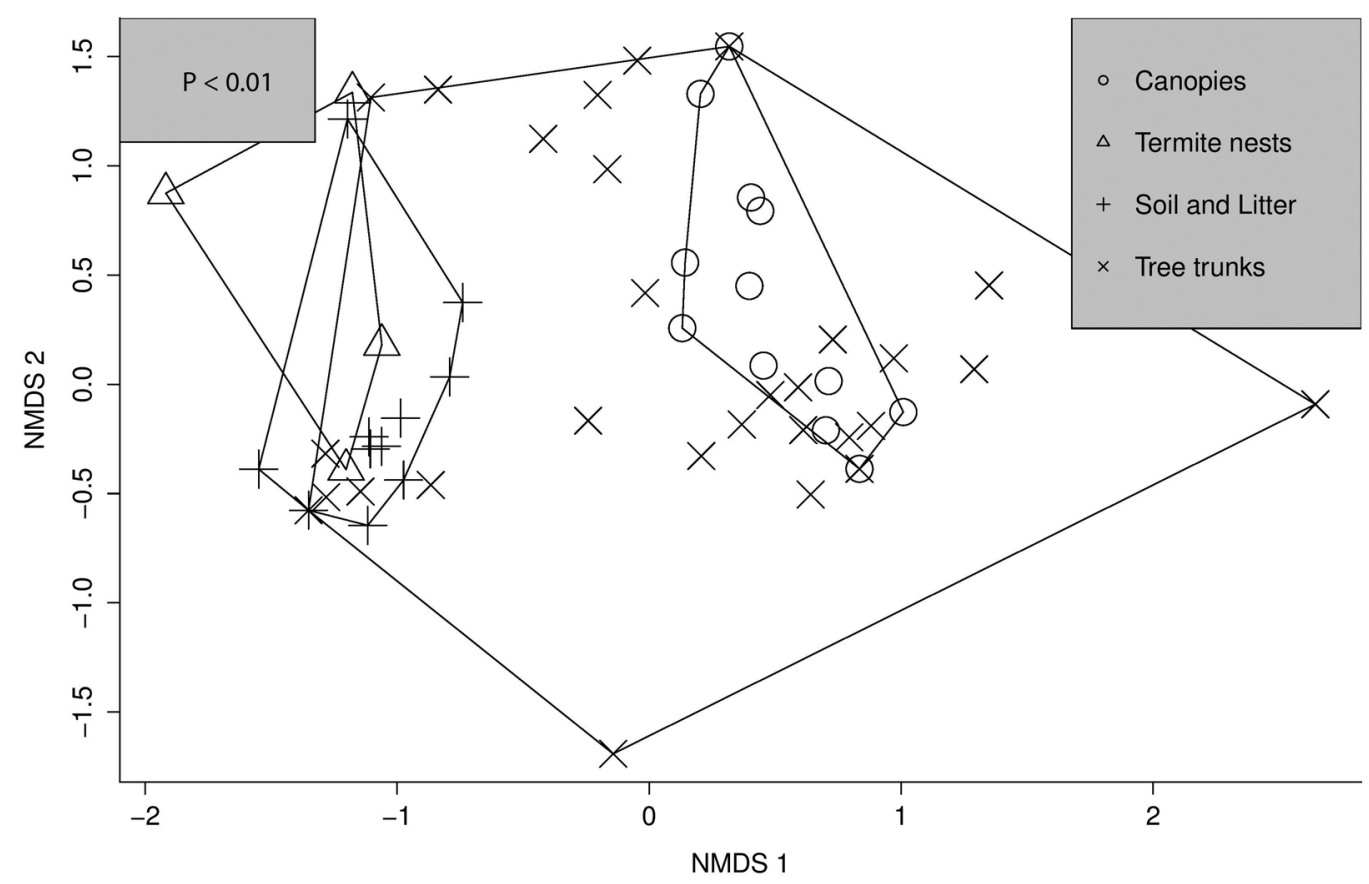

Fig. 2. Non-Metric Multidimensional Scaling (NMDS) applied to the abundance of Pseudoscorpiones in different habitats assessed in a seasonally flooded monodominant forest in the Northern region of the Pantanal of Mato Grosso, Brazil.

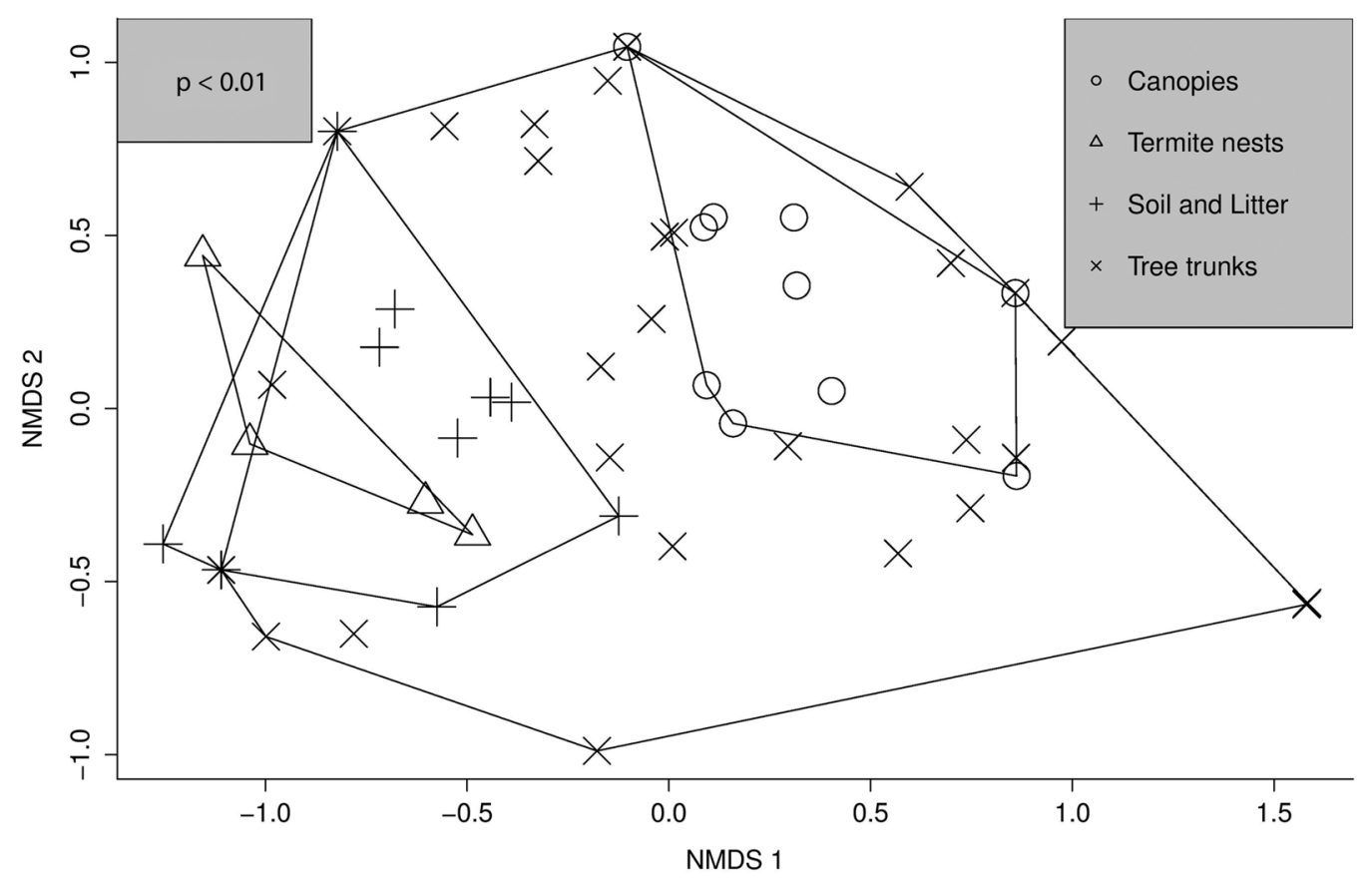

Fig. 3. Non-Metric Multidimensional Scaling (NMDS) applied to Pseudoscorpion species richness (presence-absence) in different habitats assessed on a seasonally flooded monodominant forest in the Northern region of the Pantanal of Mato Grosso, Brazil. 


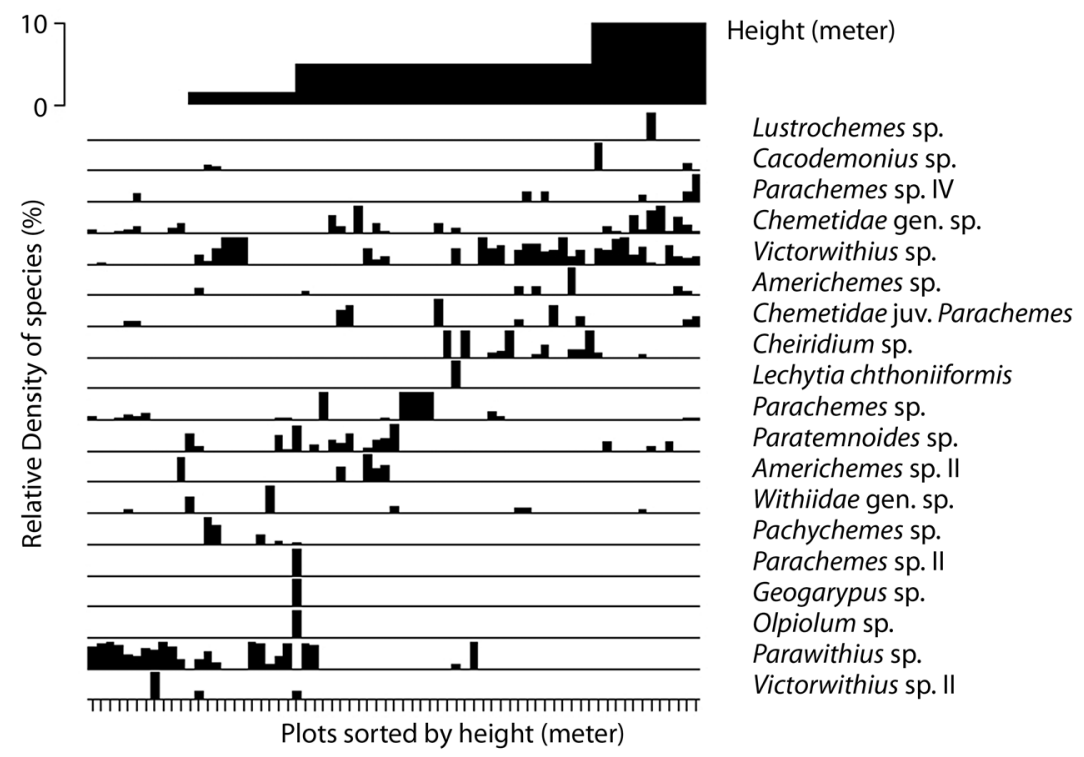

Fig. 4. Distribution gradient of Pseudoscorpion species according to habitat altitude assessed in a seasonally flooded monodominant forest in the Northern region of the Pantanal of Mato Grosso, Brazil.

\section{DISCUSSION}

Soil, tree trunks and $V$. divergens canopies are distinct habitats in relation to the assemblage of Pseudoscorpiones present in this floodplain forest in the Pantanal of Mato Grosso. In spite of the heterogeneous distribution of abundance and richness of Pseudoscorpiones among the different habitats, individual analyzes have not shown significant temporal variation in the distribution of these arachnids over the different seasonal periods. This is a different situation from that observed for other arthropod groups in the same region (Castilho et al., 2005; Battirola et al., 2007; 2009; Battirola, Marques, Brescovit, Rosado-Neto, \& Anjos, 2010; Marques et al., 2011). Although the Pseudoscorpiones constitute a very diverse group (Harvey, 2013) only 18 species were sampled, showing low species richness for this study area.

These arachnids explore various habitats (Murienne et al., 2008) and show adaptations to life in environments subject to temporal variations in their structural conditions, such as seasonally flooded areas (Adis, 1997). The main adaptations of Pseudoscorpiones to survive in seasonally flooded areas are behavioral, such as vertical soil migration to tree trunks and canopies during the high water season, as well as the phoretic behavior of some species (Adis \& Mahnert, 1993; Adis, 1997). It was observed that in the "cambarazal" each habitat has a specific assemblage. The ground environment has an elevated abundance of Pseudoscorpiones compared to other habitats (tree trunks and $V$. divergens canopies), however, a greater number of species with unique occurrence was recorded in the upper strata of this forest, showing the stratification of the Pseudoscorpiones assemblage. The low richness of species present in the soil environment may be associated with greater impact exerted by seasonal flooding on this habitat compared to the forest canopy, considering the frequency and the force exerted by the flood pulse on the biota (Junk et al., 1989).

The activity on the soil was more intense in periods leading up to the flood, or even during the high water season. This greater density of activity demonstrates that the populations of Pseudoscorpiones are influenced 
by the flooding regime, and some species have migratory behavior, moving over the soil surface while accompanying the waterline during floods. This behavior is common for Pseudoscorpiones in flooded forests in the Amazon, as well as changes in the reproduction period and, consequently, in the phenology of the species (Adis \& Mahnert, 1990a; Adis, 1997; Mahnert $\&$ Adis, 2002). Other arachnids such as soil spiders and scorpions also present similar behavior in the Pantanal in relation to the horizontal and vertical displacements caused by seasonal flooding (Battirola et al., 2010; Yamazaki, Marques, Brescovit, \& Battirola, 2015).

Both the density and the richness of Pseudoscorpiones species in the edaphic stratum in "cambarazal" were reduced when compared with the results obtained in similar studies in the Central Amazon (Adis \& Mahnert, 1985; 1990, a, b; 1993; De Morais et al., 1997). Adis and Mahnert (1990, a) affirm that in non-flooded forests, the majority of the pseudoscorpion species are terricolous, while in seasonally flooded forests there is a strong synchronization between the species phenology and flood periods, with the majority of the species in these areas being arboreal, considering the lower impact caused by the flooding of the forest. In these environments the terricolous species use the soil and leaf litter as breeding grounds during non-flood period and later migrate to tree trunks and areas of the forest canopy, where they remain during the high water season (Adis \& Mahnert, 1990, a; Adis, 1997; Mahnert \& Adis, 2002).

Adis and Mahnert (1993) obtained a higher density of Pseudoscorpiones in the soil of primary forests during the dry season and correlated these data to factors such as humidity, $\mathrm{pH}$ and temperature, showing that the distribution of Pseudoscorpiones, in different soil layers, varied according to the requirement of each species. They also found that, depending on soil conditions, some species migrate to different soil layers in response to variations in moisture in this habitat. In secondary forests, also in the Central Amazon, a greater density was found during the rainy season, but in a similar manner, the movement between soil layers was verified in accordance with changes in humidity conditions (Adis \& Mahnert, 1990, b). Weygoldt (1969) stated that humidity is one of the main factors that influence the occurrence of Pseudoscorpiones, as observed in studies in the Amazon region.

The "cambarazais" present termite nests in their interior (Cornitermes sp.), associated with elevations called mounds (Nunes-da-Cunha \& Junk, 2014). The termite mounds can be used by the Pseudoscorpiones as a habitat throughout the year, considering the unrestricted use of habitats by these arachnids, or only as a refuge during seasonal flooding (Martius, 1994; 2001; Martius, Höfer, Verhaagh, Adis, \& Mahnert, 1994). In this study a high number of Pseudoscorpiones was sampled in the termite mounds, some species in an exclusive manner, such as Parachernes sp. 2, Geogarypus sp. and Olpiolum sp.. The termite mounds usually house a number of organisms that use their structures as shelters (Martius, 1994; 2001; Costa \& Vanin, 2010). Weygoldt (1969) pointed out that the interaction between Pseudoscorpiones and social insects reaches different levels, in which the host species may or not be used as their prey, as they can feed on other animals that live in these nests such as Coleoptera larvae. In the Central Amazon the termite mounds represent important structural elements in wetland forests; however, very little study has been done on them (Martius, 1994; 2001).

Based on the occurrence of the species, the $V$. divergens tree trunks corresponded to intermediate habitats between populations of soil and canopy and can be considered as links between these forest strata, as well as a specific habitat for some taxa. The displacement rate of Pseudoscorpiones on $V$. divergens tree trunks was very low in comparison to the results obtained in the flooded forests of the Amazon, where the migration rate from the soil towards the canopy, as well as from the canopy toward the soil is quite high (Adis, 1981; 1992; 1997; De Morais et al., 1997). One of the causes of this lower migration rate of Pseudoscorpiones may be associated with lower amplitude 
and duration of floods in the Pantanal as compared to the Amazon. Or even to microhabitats available in the $V$. divergens tree trunks, provided by the fairly thick bark with many spaces that can provide shelter for these organisms during flooding (Adis et al., 2001). Thus there is no need to move up to the forest canopy, as noted in the samples of $V$. divergens tree trunks, accompanying the flood level.

Studies carried out in the Central Amazon have shown that some families have a preference for certain habitats such as Chernetidae, which in flooded forests is predominantly sampled on tree trunks and tree canopies, and Withiidae is usually associated with tree trunks (Mahnert \& Adis, 1985). In permanently flooded forest areas, also in the Amazon, Adis and Mahnert (1985) found that species richness is greater in canopies and epiphytic relative to the soil. Mahnert and Adis (1985) highlighted that in spite of the preference for habitats, there are few studies on the biology of the myrmecophilous, termitophilous, apidophilous species.

Data on the fauna associated with canopies are still scarce, constituting a field to be explored (Mahnert \& Adis, 2002). The greatest species richness in $V$. divergens canopies compared to that obtained in the soil environment is compatible to which was recorded in "igapó" areas (permanently flooded areas) in central Amazonia (Adis \& Mahnert, 1985), when they found that the canopies and epiphytes house a lot more species of Pseudoscorpiones than the forest floor. In the Pantanal, sampling in canopies of different plant species has demonstrated the importance of Pseudoscorpiones in the composition of these communities (Marques, Adis, Nunes-da-Cunha, \& Santos, 2001; Santos, Marques, Adis, \& Musis, 2003; Marques et al., 2006; Battirola, Marques, \& Adis, 2006; Battirola et al., 2007). In general, in spite of the Pseudoscorpiones assemblage presenting heterogeneous distribution among forest strata, no temporal variation was observed over the different seasonal periods for the abundance and richness of the pseudoscorpion species in each evaluated habitat, despite the specificities of each.

\section{ACKNOWLEDGMENTS}

The authors dedicate this work to Joachim Adis (in memoriam) for his devotion to the study of arthropods in floodplains and for his important contribution in preparing this paper. This study is part of the results of scientific cooperation between the Max-Planck Institute for Limnology, Plön, Germany, and the Federal University of Mato Grosso, Cuiabá, Brazil. We thank the Graduate Program in Ecology and Biodiversity Conservation, Institute of Biosciences of UFMT for the infrastructure available for the development of this research, and Pantanal Research Center (CPP), and FAPEMAT (Process 155864/2015). A.D. Brescovit received financial grant from $\mathrm{CNPq}$ (Process 303028/2014-9).

\section{RESUMEN}

Distribución vertical y temporal de Pseudoscorpiones (Arthropoda: Arachnida) en un bosque inundable del Pantanal brasileño. Los Pseudoescorpiones comprenden un diversificado grupo de arácnidos con aproximadamente 3500 especies que se han encontrado en varios hábitats como suelo, hojarasca, cuevas y copas de árboles. Este estudio tiene como objetivo evaluar la relación entre la comunidad de Pseudoscorpiones presentes en el suelo, nidos de termitas (termiteros), troncos y copas de árboles, así como también la distribución temporal de la abundancia y riqueza de especies en estos hábitats. Para esto, se usaron diferentes técnicas de muestreo en hábitats de un Bosque Monodominante Estacionalmente Inundado en la región norte del Pantanal, Estado Mato Grosso, Brasil. Datos referentes a abundancia y riqueza de especies del ensamble fueron ordenados por Escalamiento Multidimensional No Métrico (NMDS). Fueron capturados 2068 Pseudoscorpiones distribuidos en siete familias y 18 especies. Chernetidae ( $8 \mathrm{spp}$.) y Withiidae (5 spp.) predominaron. Mientras Atemnidae, Cheiridiidae, Geogarypidae, Lechytiidae y Olpiidae fueron registradas con una especie en cada una. La fauna terrícola fue más abundante (1 035 ind.; $50.0 \%$ de la captura total), con tres familias y 10 especies. Para la fauna arborícola (712 ind.; $34.4 \%$ ), cuatro familias y 13 especies fueron registradas. Los termiteros (321 ind.; $15.6 \%$ ) representaron el hábitat con menor número de individuos; sin embargo, fueron identificadas cinco familias y nueve especies, incluyendo Parachernes sp. 2, Geogarypus sp. y Olpiolum sp., que no se encuentra en otros hábitats analizados en este bosque. Los análisis estadísticos no evidenciaron variación temporal en la distribución de abundancia y riqueza de Pseudoscorpiones 
en cada hábitat evaluado; no obstante, demostraron que el ambiente edáfico (suelo y termiteros), troncos y copas de árboles son distintos en relación a la composición de la comunidad. La presencia de especies típicamente terrícolas (e.g. Parawithius sp., Withiidae gen. sp. y Parachernes sp.) y otras arborícolas (e.g. Cheiridium sp., Americhernes sp. y Lustrochernes sp.) evidencian una estratificación vertical de la comunidad de Pseudoscorpiones presente en Bosques Inundables del Pantanal brasileño.

Palabras clave: áreas inundables, Chernetidae, distribución vertical, riqueza, Withiidae.

\section{REFERENCES}

Adis, J. (1981). Comparative ecological studies of the terrestrial arthropod fauna in Central Amazonian inundation-forests. Amazoniana, 7, 87-173.

Adis, J. (1992). Überlebensstrategien terrestrischer Invertebraten in Überschwemmungswäldern Zentralamazoniens. Verhandlungen des Naturwissenschaftlicher Verein Hamburg (NF), 33, 21-114.

Adis, J. (1997). Estratégias de sobrevivência de invertebrados terrestres em florestas inundáveis da Amazônia Central: Uma resposta à inundação de longo período. Acta Amazonica, 27, 43-54. http://dx.doi. org/10.1590/1809-43921997271054

Adis, J. (2002). Taxonomical classification and biodiversity. In J. Adis (Ed.), Amazonian Arachnida and Myriapoda (pp. 13-15). Sofia: Pensoft Publishers.

Adis, J., Basset, Y., Floren, A., Hammond, P., \& Linsenmair, K. E. (1998). Canopy fogging of an overstory tree - recommendations for standardization. Ecotropica, 4, 93-97.

Adis, J., \& Harvey, M. S. (2000). How many Arachnida and Myriapoda are there world-wide and in Amazonia? Studies on Neotropical Fauna and Environment, 35, 139-141. DOI: 10.1076/0165-0521(200008)

Adis, J., \& Mahnert, V. (1985). On the natural history and ecology of Pseudoscorpiones (Arachnida) from an Amazonian blackwater inundation forest. Amazoniana, 9, 297-314.

Adis, J., \& Mahnert, V. (1990a). On the composition of Pseudoscorpiones (Arachnida) from Amazonian dryland and inundation forests in Brazil. Revue Suisse Zoologie, 97, 49-53. DOI.10.5962/bhl.part.79724

Adis, J., \& Mahnert, V. (1990b). Vertical distribution and abundance of pseudoscorpion species (Arachnida) in the soil of a Neotropical secondary forest during the dry and the rainy season. Acta Zoologica Fennica, 190, 11-16.
Adis, J., \& Mahnert, V. (1993). Vertical distribution and abundance of pseudoscorpions (Arachnida) in the soil of two different Neotropical primary forests during the dry and rainy seasons. Memoirs Queensland Museum, 33, 431-440.

Adis, J., Mahnert, V., De Morais, J. W., \& Rodrigues, J. M. G. (1988). Adaptation of an amazonian pseudoscorpion (Arachnida) from dryland forests to inundation forests. Ecology, 69, 287-291. DOI: 10.2307/1943185

Adis, J., Marques, M. I., \& Wantzen, K. M. (2001). First observations on the survival strategies of terricolous arthropods in the Northern Pantanal wetland of Brazil. Andrias, 15, 127-128.

Adis, J., \& Schubart, H. R. O. (1984). Ecological research on arthropods in Central Amazonian forest ecosystems with recomendations for study procedures. In J. H. Cooley, \& F. B. Golley (Eds.), Trends in Ecological Research for the 1980s (pp. 111-144). Nato Conference Series I: Ecology. New York: Plenun Press.

Aguiar, N. O., \& Bührnheim, P. F. (1998a). Phoretic pseudoscorpions associated with flying insects in Brazilian Amazônia. The Journal of Arachnology, 26, 452-459. http://www.jstor.org/stable/3706256

Aguiar, N. O., \& Bührnheim, P. F. (1998b). Pseudoscorpions (Arachnida) of ilha de Maracá. In W. Milliken, \& J. A. Ratter (Eds.), Maracá: The biodiversity and environment of an Amazonian rainforest (pp. 381389). Chichester: John Wiley \& Sons.

Aguiar, N. O., \& Bührnheim, P. F. (2003). Pseudoescorpiões (Arachnida) da vegetação de sub-bosque da floresta primária tropical da terra firme (Coari, Amazonas, Brasil). Acta Amazonica, 33, 515-526. http:// dx.doi.org/10.1590/S0044-59672003000300016

Aguiar, N. O., Gualberto, T. L., \& Franklin, E. (2006). A medium-spatial scale distribution pattern of Pseudoscorpionida (Arachnida) in a gradient of topography (altitude and inclination), soil factors, and litter in a Central Amazonia forest reserve, Brazil. Brazilian Journal of Biology, 66, 791-802. http://dx.doi. org/10.1590/S1519-69842006000500004

Battirola, L. D., Adis, J., Marques, M. I., \& Silva, F. H. O. (2007). Composição da comunidade de artrópodes associada à copa de Attalea phalerata Mart. (Arecaceae), durante o período de cheia no Pantanal de Poconé, Mato Grosso, Brasil. Neotropical Entomology, 36, 640-651. http://dx.doi.org/10.1590/ S1519-566X2007000500002

Battirola, L. D., Marques, M. I., \& Adis, J. (2006). The importance of organic material for arthropods on Attalea phalerata (Arecaceae) in the Pantanal of Mato Grosso, Brazil. What's up? ICAN, 12, 1-3.

Battirola, L. D., Marques, M. I., Adis, J., \& Brescovit, A. D. (2004). Aspectos ecológicos da comunidade de Araneae (Arthropoda, Arachnida) em copas da palmeira 
Attalea phalerata Mart. (Arecaceae) no Pantanal de Poconé, Mato Grosso, Brasil. Revista Brasileira de Entomologia, 48, 421-430. http://dx.doi.org/10.1590/ S0085-56262004000300020

Battirola, L. D., Marques, M. I., Brescovit, A. D., RosadoNeto, G. H., \& Anjos, K. C. (2010). Comunidade edáfica de Araneae (Arthropoda, Arachnida) em uma floresta sazonalmente inundável na região norte do Pantanal de Mato Grosso, Brasil. Biota Neotropica, 10, 173-183. http://dx.doi.org/10.1590/ S1676-06032010000200022

Battirola, L. D., Marques, M. I., Rosado-Neto, G. H., Pinheiro, T. G., \& Pinho, N. G. C. (2009). Vertical and time distribution of Diplopoda (Arthropoda: Myriapoda) in a monodominant forest in Pantanal of Mato Grosso, Brazil. Zoologia, 26, 479-487. http://dx.doi. org/10.1590/S1984-46702009005000008

Castilho, A. C. C., Marques, M. I., Adis, J., \& Brescovit, A. D. (2005). Distribuição sazonal e vertical de Araneae em área com predomínio de Attalea phalerata Mart. (Arecaceae), no Pantanal de Poconé, Mato Grosso, Brasil. Amazoniana, 18, 215-239.

Clarke, K. R. (1993). Non-parametric multivariate analyses of changes in community structure. Australian Journal of Ecology, 18, 117-143. DOI: 10.1111/j.14429993.1993.tb00438.x

Costa, C., \& Vanin, A. S. (2010). Coleoptera larval fauna associated with termite nests (Isoptera) with emphasis on the bioluminescent termite nests from Central Brazil. Psyche, 2010, 1-13, http:// dx.doi. org $/ 10.1155 / 2010 / 723947$

De Morais, J. W., Adis, J., Mahnert, V., \& Berti-Filho, E. (1997). Abundance and phenology of Pseudoscorpiones (Arachnida) from a mixedwater inundation forest in Central Amazonia, Brazil. Revue Suisse Zoologie, $104,475-483$.

Harvey, M. S. (2013). Order Pseudoscorpiones. In Z. Q. Zhang (Ed.), Animal Biodiversity: An outline of higher-level classification and survey of taxonomic richness (Arachnida). Zootaxa, 3703, 1-82.

Heckman, C. W. (1998). The Pantanal of Poconé. Biota and ecology in the northern section of the world's largest pristine wetland. Dordrecht, Kluwer: Academic Publishers. DOI: http://dx.doi. org/10.1007/978-94-017-3423-3

Junk, W. J. (1997). General aspects of floodplain ecology with special reference to Amazonian Floodplains. In W. J. Junk (Ed.), The Central Amazon Floodplain. Ecology of a pulsing system (pp. 455-472). Berlin, Springer: Ecological Studies 126.

Junk, W. J., Bayley, P. B., \& Sparks, R. E. (1989). The flood pulse concept in river-floodplain systems. In D. P. Dodge (Ed.), Proceedings of the International Large River Symposium (LARS) (pp. 110-127).
Ontario: Canadian Special Publication of Fisheries and Aquatic Sciences 106.

Legendre, P., \& Legendre, L. (1998). Numerical Ecology (2nd ed.). Amsterdam: Elsevier Science.

Mahnert, V. (2009). Attaleachernes gen. nov., a new Chernetid genus from palm trees in the Brazilian Pantanal (Pseudoscorpiones: Chernetidae). Contributions Natural History, 12, 921-930.

Mahnert, V., \& Adis, J. (1985). On the occurrence and habitat of Pseudoscorpiones (Arachnida) from Amazonian Forest of Brazil. Studies on Neotropical Fauna and Environment, 20, 211-215. http://dx.doi. org/10.1080/01650528509360691

Mahnert, V., \& Adis, J. (2002). Pseudoscorpiones. In J. Adis (Ed.), Amazonian Arachnida and Myriapoda (pp. 367-380). Sofia: Pensoft Publishers.

Marques, M. I., Adis, J., Battirola, L. D., Santos, G. B., \& Castilho, A. C. C. (2011). Arthropods associated with a forest of Attalea phalerata Mart. (Arecaceae) palm trees in the northern Pantanal of the Brazilian state of Mato Grosso. In W. J. Junk, C. J. Da-Silva, C. Nunesda-Cunha, \& K. M. Wantzen (Eds), The Pantanal: Ecology, biodiversity and sustainable management of a large neotropical seasonal wetland (pp. 431-468). Sofia-Moscow: Pensoft Publishers.

Marques, M. I., Adis, J., Nunes-da-Cunha, C., \& Santos, G. B. (2001). Arthropod biodiversity in the canopy of Vochysia divergens (Vochysiaceae), a forest dominant in the Brazilian Pantanal. Studies on Neotropical Fauna and Environment, 36, 205-210. http://dx.doi. org/10.1076/snfe.36.3.205.2122

Marques, M. I., Adis, J., Santos, G. B., \& Battirola, L. D. (2006). Terrestrial arthropods from tree canopies in the Pantanal of Mato Grosso, Brazil. Revista Brasileira de Entomologia, 50, 257-267. http://dx.doi. org/10.1590/S0085-56262006000200007

Martius, C. (1994). Termite nests as structural elements of the Amazon floodplain forest. Andrias, 13, 137-150.

Martius, C. (2001). Nest architecture of Nasutitermes termites in a white water floodplain forest in Central Amazonia, and a field key to species (Isoptera, Termitidae). Andrias, 15, 163-171.

Martius, C., Höfer, H., Verhaagh, M., Adis, J., \& Mahnert, V. (1994). Terrestrial arthropods colonizing an abandoned termite nest in a floodplain forest of the Amazon River during the flood. Andrias, 13, 17-22.

Murienne, J., Harvey, M. S., \& Giribet, G. (2008). First molecular phylogeny of the major clades of Pseudoscorpiones (Arthropoda: Chelicerata). Molecular Phylogenetics and Evolution, 49, 170-184. http:// dx.doi.org/10.1016/j.ympev.2008.06.002 
Nunes-da-Cunha, C., \& Junk, W. J. (2004). Year-toyear changes in water level drive the invasion of Vochysia divergens in Pantanal grasslands. Applied Vegetation Science, 7, 103-110. DOI: 10.1111/j.1654109X.2004.tb00600.x

Nunes-da-Cunha, C., \& Junk, W. J. (2011). A preliminary classification of habitats of the Pantanal of Mato Grosso and Mato Grosso do Sul, and its relation to national and international wetland classification systems. In W. J. Junk, C. J. Da-Silva, C. Nunesda-Cunha, \& K. M. Wantzen (Eds.), The Pantanal: Ecology, biodiversity and sustainable management of a large neotropical seasonal wetland (pp. 127-141). Sofia-Moscow: Pensoft Publishers.

Nunes-da-Cunha, C., \& Junk, W. J. (2014). A classificação dos macrohabitats do Pantanal Mato-grossense. In C. Nunes-da-Cunha, M. T. F. Piedade, \& W. J. Junk (Eds.), Classificação e delineamento das áreas úmidas brasileiras e de seus macrohabitats (pp. 77-122). Cuiabá: EdUFMT.

Oksanen, J., Kindt, R., Legendre, P., O'hara, B., Stevens, M. H. H., \& Oksanen, M. J. (2014). Suggests, M.A.S.S. 2014. VEGAN: Community Ecology Package. $\mathrm{R}$ package version 2.002. http://CRAN.Rproject.org/package=vegan. Accessed 17 Nov. 2014

Pinho, N. G. C. (2003). Diversidade da artropodofauna em solo no Pantanal de Poconé, Mato Grosso (Dissertação de Mestrado). Instituto de Biociências, UFMT, Cuiabá, MT.

Ponce, V. M., \& Nunes-da-Cunha, C. (1993). Vegetated earthmounds in tropical savannas of Central Brazil: a synthesis with special reference to the Pantanal of Mato Grosso. Journal of Biogeography, 20, 219-225. DOI: $10.2307 / 2845673$

Por, F. D. (1995). The Pantanal of Mato Grosso (Brazil). World's largest Wetlands. Dordrecht: Kluwer Academic Publishers.

R Core Team. (2013). R: A language and environment for statistical computing. R Foundation for Statistical Computing, Vienna, Austria. URL http://www.Rproject.org/

Santos, G. B., Marques, M. I., Adis, J., \& Musis, C. R. (2003). Artrópodos associados à copa de Attalea phalerata Mart. (Arecaceae), na região do Pantanal de Poconé, Mato Grosso, Brasil. Revista Brasileira de Entomologia, 47, 211-224. http://dx.doi.org/10.1590/ S0085-56262003000200010

Silva, M. P., Mauro, R., Mourão, G., \& Coutinho, M. (2000). Distribuição e quantificação de classes de vegetação do Pantanal através de levantamento aéreo. Revista Brasileira de Botânica, 23, 143-152. DOI: http:// dx.doi.org/10.1590/s0100-84042000000200004

Weygoldt, P. (1969). Biology of Pseudoscorpions. Cambridge: Harvard University Press.

Yamazaki, L., Marques, M. I., Brescovit, A. D., \& Battirola, L. D. (2015). Tityus paraguayensis (Scorpiones: Buthidae) em copas de Callisthene fasciculata (Vochysiaceae) no Pantanal de Mato Grosso (Brasil). Acta Biológica Paranaense, 44, 153-158. http:// dx.doi.org/10.5380/abpr.v44i1-4.44122 
